\title{
O TRÁFICO DE ESCRAVOS VELHOS (PROVÍNCIA DE SÃO PAULO, 1861-1887)
}

\author{
The Traffic of Aged Slaves \\ (Province of São Paulo, 1861-1887) \\ José Flávio Motta*
}

\begin{abstract}
RESUMO
Estudamos os escravos velhos no Brasil da segunda metade do século XIX. Mais especificamente, analisamos a participação dos idosos no fluxo de escravos negociados nas localidades paulistas de Areias, Guaratinguetá, Constituição (Piracicaba) e Casa Branca no período de 1861 a 1887. De início, procedemos à definição da faixa etária que abrange o contingente analisado: 50 ou mais anos. Em seguida, delineamos brevemente algumas características dos municípios escolhidos, com o foco na expansão cafeeira na província de São Paulo. Examinamos então as transações registradas nas localidades referidas e as características das pessoas idosas que compuseram as ditas transações. Entre os resultados observados, destacamos a participação dos cativos velhos no conjunto de indivíduos traficados inversamente relacionada à intensidade do comércio de escravos, a grande supremacia dos idosos do sexo masculino e dos negócios locais e a crescente idade média dos velhos transacionados. Notamos haver negócios decorrentes de uma demanda direta por esses idosos, bem como haver transações nas quais eles eram parte necessária para viabilizar o acesso à mão de obra de familiares seus, fossem estes igualmente cativos, livres ou libertos. Na quarta seção alinhavamos nossas considerações finais.
\end{abstract}

Palavras-chave: escravos idosos; tráfico interno de escravos; expansão cafeeira paulista.

* Professor do Departamento de Economia da FEA/USP, do Programa de Pós-Graduação em Economia do IPE-FEA/USP e do Programa de Pós-Graduação em História Econômica da FFLCH/USP; membro do N.E.H.D. - Núcleo de Estudos em História Demográfica da FEA/USP, e do HERMES \& CLIO - Grupo de Estudos e Pesquisa em História Econômica da FEA/USP. E-mail: jflaviom@usp.br. Este texto é resultado de pesquisa presentemente vinculada a uma bolsa de produtividade concedida pelo Conselho Nacional de Desenvolvimento Científico e Tecnológico - CNPq. 


\begin{abstract}
This article studies aged slaves in Brazil on the second half of the 19th century. More specifically we analyze the rates of aged slaves in total numbers of slaves traded from 1861 to 1887 in the paulista localities of Areias, Guaratinguetá, Constituição (Piracicaba) and Casa Branca. First we define 50 years and over as the age bracket for the group that is the subject of the study. Then we outline some characteristics of the selected localities, focusing on the expansion of coffee plantation in the province of São Paulo. Finally we examine the transactions registered in the selected localities and the characteristics of the aged slaves involved. We found, among other important results, that the rates of aged slaves traded were inversely proportional to the volume of total trade in slaves; that the bulk of the transactions involved male aged slaves and local deals; and that the average age of the aged slaves traded increased in time. We found that there were dealings resulting from a direct demand for aged slaves, and also that in some dealings aged slaves were a necessary part in transactions that had in mind the access to the labour of slaved, free or freed persons that were relatives of those aged slaves. Our final considerations are presented in the fourth section.
\end{abstract}

Key words: aged slaves; internal slave trade; expansion of coffee plantation in São Paulo.

Em tempo: o escravo David é apenas vendido os seus serviços e não a sua pessoa, visto ser maior de sessenta anos como consta da matrícula acima transcrita.

Excerto de uma escritura de compra e venda de escravos, datada aos $5 / 12 / 1885$.

\title{
Sobre velhos e escravos
}

Nestes princípios do terceiro milênio, resta assentado com nitidez o recorte etário definidor da população da assim chamada "terceira idade". De fato, cá no Brasil, por exemplo, em 2003, no Dia Internacional do Idoso 
(1. ${ }^{\circ}$ de outubro), o Presidente Luiz Inácio Lula da Silva sancionou a Lei n. ${ }^{\circ}$ 10.741, dispondo sobre o Estatuto do Idoso. Em seu Artigo $1 .^{\circ}$, a lei explicita a faixa etária a abranger as pessoas contempladas: 60 (sessenta) ou mais $\operatorname{anos}^{1}$. No site do Instituto Brasileiro de Geografia e Estatística - IBGE -, os dados tabulados do Censo de 2000 permitem verificar que, numa população residente de 169.799.170 pessoas, pouco menos de 9\% (14.536.929) compunham o contingente de idosos. Essa proporção repete-se ao tomarmos isoladamente os números para o Estado de São Paulo: 3.316 .957 indivíduos com 60 ou mais anos de idade numa população residente de 37.032.403 habitantes.

Seria o caso de trabalharmos com esse mesmo recorte etário para o século XIX? Como esperado, dados do Primeiro Recenseamento Geral do Império referentes à Província de São Paulo, realizado há pouco menos de 140 anos, revelam, comparados aos do Censo de 2000, uma participação menor das pessoas mais velhas: $5,8 \%{ }^{2}$. No cálculo deste último porcentual, porém, estamos nos atendo à população livre: 39.191 pessoas com 61 anos ou mais, num total provincial de 680.742 indivíduos livres ${ }^{3}$. No que tange aos escravos, os informes censitários ressentiam-se dos efeitos dos mais de 20 anos desde a extinção do tráfico transatlântico de cativos, em 1850, e também da libertação do ventre da escrava, em setembro de 1871. Eram, à época do censo, 14.408 escravos com 61 ou mais anos de idade na província paulista, numa população cativa de 156.612 pessoas, ou seja,

1 A preocupação com as pessoas de idade mais avançada não é, evidentemente, apenas brasileira. O artigo 2. ${ }^{\circ}$ da Political Declaration que acompanha o Madrid International Plan of Action on Ageing (documentos resultantes da Second World Assembly on Ageing, realizada sob os auspícios da ONU em 2002), evidencia a dita preocupação: "We recognize that the world is experiencing an unprecedented demographic transformation and that by 2050 the number of persons aged 60 years and over will increase from 600 million to almost 2 billion and that the proportion of persons aged 60 years and over is expected to double from 10 to 21 per cent. The increase will be greatest and most rapid in developing countries where the older population is expected to quadruple during the next 50 years." (UNITED NATIONS. Report of the Second World Assembly on Ageing: Madrid, 8-12 April 2002. United Nations publication: New York, 2002, p. 1)

2 Para esses dados da província paulista, servimo-nos das tabulações constantes de BASSANEZI, Maria Sílvia C. Beozzo (Org.). São Paulo do passado: dados demográficos. Campinas: NEPO-Núcleo de Estudos em População/UNICAMP, 1998. 1 CD-ROM.

3 Para a grande maioria das províncias do Império, o Recenseamento foi realizado em $1 .^{\circ} \mathrm{de}$ agosto de 1872. Não foi o que ocorreu em São Paulo, onde a data do censo foi aos 30 de janeiro de 1874. Cabe observar que o cômputo das pessoas com 60 anos elevaria decerto o porcentual mencionado; se, dos 32.871 indivíduos livres com idades entre 51 e 60 anos, 3.287 (10\%) tivessem 60 anos completos, aquele porcentual elevar-se-ia de $5,8 \%$ para $6,2 \%$. 
$9,2 \%$ de idosos ${ }^{4}$. Essas disparidades entre os contingentes de livres e de cativos levam-nos a reformular a questão que abre este parágrafo: seria o recorte etário dos 60 anos ou mais apropriado para identificar os "escravos da terceira idade"?

Para responder a esta questão, lembremos que, pouco mais de uma década após o Recenseamento Geral e ainda no reinado de D. Pedro II, aos 28 de setembro de 1885 , foi promulgada a Lei . $^{\circ} 3.270$, regulando a extinção gradual do elemento servil. Ela passou para a história como a Lei dos Sexagenários. Abaixo reproduzimos alguns parágrafos de seu Artigo 3. ${ }^{\circ}$, que tratava das alforrias e dos libertos:

$\S 10$ - São libertos os escravos de 60 anos de idade, completos antes e depois da data em que entrar em execução esta Lei; ficando, porém, obrigados, a título de indenização pela sua alforria, a prestar serviços a seus ex-senhores pelo espaço de três anos. $\S 11$ - Os que forem maiores de 60 e menores de 65 anos, logo que completarem esta idade, não serão sujeitos aos aludidos serviços, qualquer que seja o tempo que os tenham prestado com relação ao prazo acima declarado.

$\S 12$-É permitida a remissão dos mesmos serviços, mediante o valor não excedente à metade do valor arbitrado para escravo da classe de 55 a 60 anos de idade. [este valor arbitrado era de Rs. $200 \$ 000$ para homens e Rs. $150 \$ 000$ para mulheres-JFM] $\S 13$ - Todos os libertos maiores de 60 anos, preenchido o tempo de serviço de que trata o $\S 10$, continuarão em companhia de seus ex-senhores, que serão obrigados a alimentá-los, vesti-los, e tratá-los em suas moléstias, usufruindo os serviços compatíveis com as forças deles, salvo se preferirem obter em outra parte os meios de subsistência, e os Juízes de Órfãos os julgarem capazes de o fazer ${ }^{5}$.

Assim sendo, os dizeres da Lei dos Sexagenários sancionariam, em uma primeira aproximação, o procedimento de tomarmos a idade de 60 anos

4 Porcentual que se elevaria para $10 \%$ se somadas a essas 14.408 pessoas um décimo dos 11.806 escravos com idades de 51 a 60 anos, como uma estimativa do número dos que teriam 60 anos completos.

5 Cf. Coleção de Leis do Império do Brasil, 1808-1889. Atos do Poder Legislativo de 1885. Disponível em: <http://www2.camara.gov.br/legislacao/publicacoes/doimperio>. Acesso em: 19 de maio de 2008. Na transcrição do trecho da lei optamos por manter a pontuação do texto original, ao passo que atualizamos a ortografia, opção adotada em todos os casos similares ao longo deste artigo. 
como "piso" definidor do contingente de idosos para o qual voltamos nossa atenção neste artigo. Tais dizeres sugeririam, poder-se-ia até mesmo aventar, o uso do parâmetro dos 65 anos para esse "piso". Afinal, a participação relativa dos sexagenários no conjunto dos cativos naqueles anos próximos à abolição da escravatura talvez fosse relativamente expressiva. De acordo com Robert Conrad, ao comentar o impacto da Lei n. ${ }^{\circ} 3.270$, para o Império como um todo, "as estatísticas oficiais colocavam o número de cativos de sessenta anos ou mais em 90.713 (...)"'. Levando em conta não chegarem a 750 mil os escravos contabilizados na matrícula de 1887, as estatísticas oficiais mencionadas apontariam para uma participação aproximada de 12\% dos cativos idosos. Este último porcentual, ressalvemos, estaria inflado pelos cerca de três lustros de vigência da Lei do Ventre Livre. Não obstante, o mesmo brasilianista completou sua frase acima transcrita do seguinte modo: “(...) mas apenas 18.946 pessoas foram registradas como sexagenárias em 1886 e 1887'. Esta última cifra, que levou Conrad a questionar o sucesso da lei de 1885, se utilizada no lugar da anterior, de 90.713, acarretaria significativa redução da participação dos escravos idosos, para algo como $2,5 \%$ do conjunto da escravaria.

Por outro lado, é mais que evidente o colossal hiato entre os objetivos do Estatuto do Idoso, "destinado a regular os direitos assegurados às pessoas com idade igual ou superior a 60 (sessenta) anos" ", e as poucas obrigações impostas aos ex-senhores dos escravos sexagenários libertados, explicitadas no $\S 13$ da Lei n. ${ }^{\circ} 3.270$. Não pretendemos cometer a temeridade de comparar documentos produzidos em contextos tão díspares. Mas vale a pena rememorarmos as palavras de Caio Prado Júnior sobre a lei de setembro de 1885: "uma estrondosa gargalhada repercutirá pelo país. Ninguém levou a sério o que a reação escravocrata pretendia apresentar como uma larga e generosa concessão"».

A esse entendimento de Caio Prado parece corresponder, por exemplo, a relevância adquirida pelos cativos idosos no delineamento do padrão

6 CONRAD, Robert. Os últimos anos da escravatura no Brasil, 1850-1888. 2. ed. Rio de Janeiro: Civilização Brasileira, 1978, p. 279. Em nota de rodapé, esse autor fornece suas fontes para tais informes: Gazeta da Tarde, de 13 de abril de 1885; Correio Paulistano, de 16 de setembro de 1887; e o Relatório do Ministério da Agricultura, de 13 de maio de 1887.

7 Cf. Artigo $1 .^{\circ}$ da Lei n. ${ }^{\circ} 10.741$, de $1 .^{\circ}$ de outubro de 2003.

8 PRADO JR., Caio. História econômica do Brasil. 20. ed. São Paulo: Brasiliense, 1977, p. 181. 
das alforrias sintetizado por Jacob Gorender. Aplicável não apenas ao ocaso do período escravista, uma das características definidoras de tal padrão seria o "elevado porcentual de velhos e inválidos em geral entre os alforriados". Figuravam, por conseguinte, os velhos, entre os cativos "que os senhores jogavam na rua sem precisar passar por escrito o atestado de sua crueldade". Gorender fez referência aos inúmeros e contundentes testemunhos,

como os de Vilhena, Koster, Saint-Hilaire, Cunha Mattos, Maria Graham, Debret e Correa Júnior, que revelam o quanto constituía prática generalizada, desde o Nordeste a Minas Gerais e Goiás, na Corte do Império e no Vale do Paraíba da época do café, a de libertar os escravos velhos e inválidos, deixando-os ao desamparo e eliminando dos custos do engenho, da fazenda ou da casa residencial, os gastos com servidores inutilizados ${ }^{9}$.

Dessa forma, não se nos afigura como um absurdo aventarmos que, ao explicitar o "público-alvo" da Lei n. ${ }^{\circ} 3.270$, os legisladores tenham fixado um parâmetro o qual, fosse seu objetivo precípuo o benefício dos escravos, poderia ser entendido como demasiadamente elevado. Mas a preocupação maior a nortear a ação dos legisladores, assim nos parece, era com a disponibilidade de mão de obra para a utilização na lavoura e, por conta disso, a tentativa de prolongar o mais possível a vigência da instituição servil. Mostram-se, portanto, muito coerentes esses três outros parágrafos da Lei dos Sexagenários, de números 15, 17 e 18, que tratavam não exclusivamente das pessoas de idade mais avançada, igualmente extraídos de seu Artigo 3. ${ }^{\circ}$, dedicado ao tema das alforrias e dos libertos:

$\S 15$ - O que se ausentar de seu domicílio será considerado vagabundo e apreendido pela Polícia para ser empregado em trabalhos públicos ou colônias agrícolas.

[...]

$\S 17$ - Qualquer liberto encontrado sem ocupação será obrigado a empregar-se ou a contratar seus serviços no prazo que lhe for marcado pela Polícia.

9 GORENDER, Jacob. O escravismo colonial. 4. ed. rev. e ampliada. São Paulo: Ática, 1985, p. 355 . 
$\S 18$ - Terminado o prazo, sem que o liberto mostre ter cumprido a determinação da Polícia, será por esta enviado ao Juiz de Órfãos, que o constrangerá a celebrar contrato de locação de serviços, sob pena de 15 dias de prisão com trabalho e de ser enviado para alguma colônia agrícola no caso de reincidência ${ }^{10}$.

Acertadamente, baseando-se em manifestações de diversos parlamentares, a exemplo do deputado Valadares, do Partido Liberal, Joseli Mendonça, no seu mestrado focado no estudo da Lei Saraiva-Cotegipe, em capítulo com muita propriedade intitulado "O liberto com que se sonhava", escreveu:

A grande questão era, portanto, a continuidade da produção da grande lavoura de exportação. (...) Ocorrendo a emancipação, dizia [o deputado Valadares-JFM], os libertos necessariamente dispersariam e o resultado seria inevitavelmente a escassez do elemento de trabalho para a produção agrícola. O problema se agravava ainda mais quando se considerava a exclusão da população feminina dos trabalhos na lavoura. "Feita a emancipação", dizia, "as mulheres, naturalmente, irão desempenhar os seus misteres domésticos". Disso decorreria um agravamento na diminuição do número de trabalhadores, "em detrimento das rendas públicas"11.

Em consonância com as reflexões até aqui expostas evitaremos, na definição utilizada neste artigo do segmento formado pelos idosos, a mera replicação do recorte dos 60 anos, referencial adotado na lei de 1885 e consagrado, em nossos dias, pelo Estatuto do Idoso. Consideremos, alternativamente, as estimativas de longevidade de escravos no Brasil na segunda metade do século XIX, elaboradas por Pedro Carvalho de Mello ${ }^{12}$. Em especial, tomemos os resultados desse autor para a expectativa de vida do contingente amiúde preferido para a composição dos plantéis de cativos,

10 Cf. Coleção de Leis..., op. cit.

11 MENDONÇA, Joseli Maria Nunes. Entre a mão e os anéis: a Lei dos Sexagenários e os caminhos da abolição no Brasil. Campinas: Editora da UNICAMP/CECULT/FAPESP, 1999, p. 70.

12 Cf. MELLO, Pedro Carvalho de. Estimativa da longevidade de escravos no Brasil na segunda metade do século XIX. Estudos Econômicos, São Paulo, v. 13, n. 1, p. 151-179, jan./abr. 1983. 
isto é, os adultos jovens, assim entendidas as pessoas com idades de 15 a 29 anos. Nas estimativas de Mello, os escravos homens com 15 anos teriam uma expectativa de vida entre 29,85 e 32,30 anos; os intervalos correlatos para os homens com 20, 25 e 30 anos igualaram-se, respectivamente, a: 26,76 a 29,$18 ; 24,11$ a 26,02; e 21,63 a 23,28 anos. Os resultados para as escravas adultas jovens foram sempre superiores, oscilando entre 1,5 e 2,5 anos a mais em sua expectativa de vida $v i s-\grave{a}$-vis as pessoas do sexo oposto. Ou seja, os cativos na faixa etária dos 15 aos 29 anos teriam uma esperança de vida que, se concretizada, levá-los-ia a uma idade em torno dos 50 anos $^{13}$.

Ora, esse recorte dos 50 anos já havia sido também utilizado pela legislação acerca dos escravos. Foi o que ocorreu no Decreto n. ${ }^{\circ} 5.135$, de 13 de novembro de 1872, que aprovou o regulamento geral para a execução da Lei n. ${ }^{\circ} 2.040$, de 28 de setembro de 1871 (a Lei do Ventre Livre). Em trabalho anterior, fizemos referência ao capítulo II do aludido regulamento, no qual se tratava do Fundo de Emancipação:

em seu artigo 27, estabeleceu-se que a alocação dos recursos para emancipação deveria obedecer à seguinte ordem: em primeiro lugar, libertar-se-iam as famílias escravas; em sequência, os indivíduos. Na libertação por famílias, a classificação prevista era: $1 .^{\circ}$ ) os cônjuges que fossem escravos de diferentes senhores; $2 .^{\circ}$ ) os cônjuges que tivessem filhos nascidos livres em virtude da lei n. ${ }^{\circ} 2.040$ e menores de oito anos; $3 .^{\circ}$ ) os cônjuges que tivessem filhos livres menores de vinte e um anos; $4^{\circ}$ ) os cônjuges com filhos menores escravos; $5^{\circ}$ ) as mães com filhos menores escravos; $\left.6 .^{\circ}\right)$ os cônjuges sem filhos menores. Os demais cativos eram também ordenados: $\left.1 .^{\circ}\right)$ mãe ou pai com filhos livres; $2 .^{\circ}$ ) os de doze a cinquenta anos de idade, começando pelos mais moços do sexo feminino, e pelos mais velhos do sexo masculino ${ }^{14}$.

$13 \mathrm{O}$ autor em questão, ademais, observou que "os resultados que encontramos para a expectativa de vida ao nascer de um escravo do sexo masculino - que estimamos entre 18 e 23 anos - sustentam as interpretações que apontam as condições de mortalidade vigentes no Brasil muito mais próximas das de Cuba, Índias Ocidentais e Suriname do que da experiência dos Estados Unidos. A expectativa de vida ao nascer para um escravo do sexo masculino foi avaliada como de 18 anos na Jamaica e de 35,5 no sul dos Estados Unidos em 1850" (MELLO, op. cit., p. 168).

14 MOTTA, José Flávio; MARCONDES, Renato Leite. A família escrava em Lorena e Cruzeiro (1874). População e Família, São Paulo, CEDHAL/USP, n. 3, p. 93-128, 2000, p. 95, grifos nossos. 
De fato, os interesses escravistas igualmente pareciam entender os 50 anos como um parâmetro relevante. Robert Conrad mencionou alguns anúncios publicados em jornais das províncias "do norte", mediante os quais se propunha a compra de cativos destinados ao mercado do centro-sul cafeeiro. Tais anúncios inegavelmente refletiam as demandas dos cafeicultores, e houve neles referência explícita àquele marco etário, que aparecia como um limite superior a balizar o desejo de potenciais compradores da mercadoria humana:

(...) O Paiz [jornal de São Luiz do Maranhão-JFM] publicou anúncios [em 1880-JFM] afirmando que estavam sendo pagos bons preços no Hotel Porto por escravos de ambos os sexos entre doze e vinte anos de idade; e que a firma Melchior \& Cia. compraria cativos sem especializações e até cinquenta $\underline{\text { anos de idade }}^{15}$.

Em suma, entendemos que as idades de 60 ou 65 anos, explicitadas como parâmetros na Lei dos Sexagenários, são muito elevadas para servirem como limites inferiores da categoria de "escravos idosos" com a qual trabalhamos. Adicionalmente, valemo-nos do trabalho de Mello acima referido, buscando indicações para um parâmetro alternativo. Por fim, e mesmo correndo o risco de incorporar certa dose de arbitrariedade, as indicações selecionadas nortearam nossa opção pelo cômputo, como cativos idosos, daqueles com idades iguais ou superiores a 50 anos. Esse procedimento, de resto, parece coadunar-se com inferências extraídas da legislação e de anúncios de jornais da segunda metade do Oitocentos, reveladores dos interesses dos próprios escravistas.

\section{As localidades selecionadas}

Definida a faixa etária daqueles a quem denominamos escravos velhos, é necessário esclarecer que estaremos preocupados com um contingente específico das pessoas incluídas na faixa etária em questão. Nossa análise

15 CONRAD, op. cit., p. 72, grifos nossos. 
volta-se à caracterização dos indivíduos de mais idade que foram objeto do tráfico interno de cativos. Mais especificamente, trataremos dos idosos que integraram transações cujas respectivas escrituras foram registradas em alguns municípios paulistas selecionados no período de 1861 a 1887 . Nesta seção, delineamos sucintamente os vínculos entre tais municípios e a cafeicultura, bem como fornecemos sua localização no mapa de São Paulo (Figura 1). As quatro localidades escolhidas, Areias, Guaratinguetá, Constituição (Piracicaba) e Casa Branca, sofreram o condicionamento advindo do movimento de expansão da lavoura cafeeira em São Paulo, todavia em momentos diferenciados e a partir de contextos específicos.

Areias, situada no Vale do Paraíba paulista, tornou-se vila em 1817, desmembrada do Município de Lorena, e em 1857 foi elevada à categoria de cidade $^{16}$. Ainda como freguesia foi, de acordo com Taunay, uma das duas

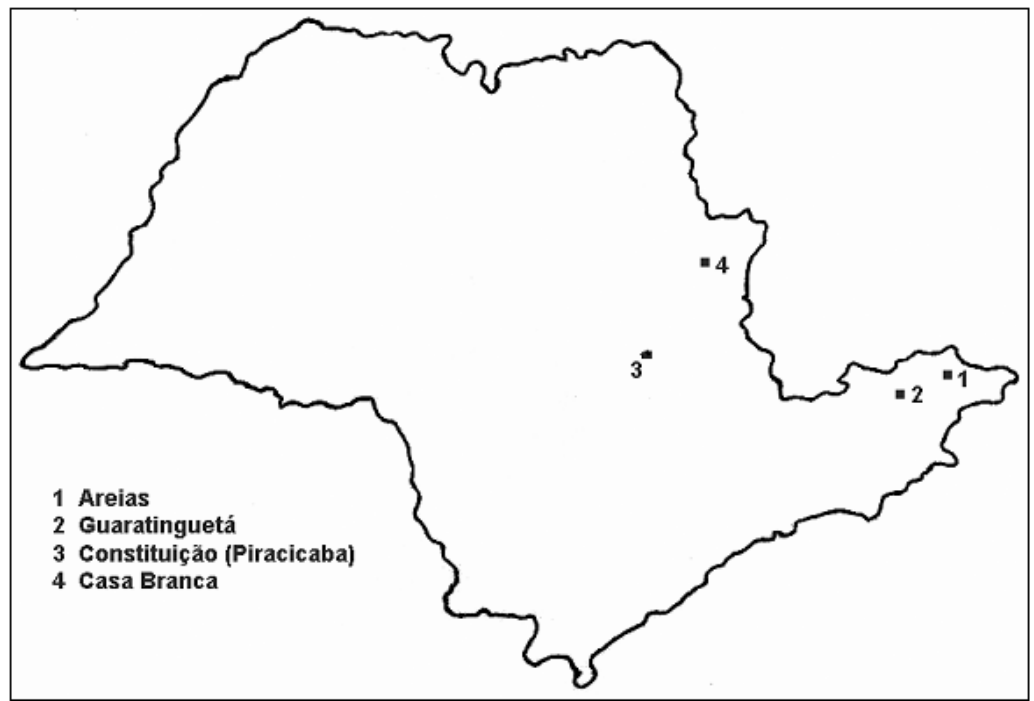

16 Cf. LUNÉ, Antonio José Baptista de; FONSECA, Paulo Delfino da (Orgs.). Almanak da província de São Paulo para 1873. Ed. fac-similada. São Paulo: Imprensa Oficial do Estado-IMESP, Arquivo do Estado de São Paulo, 1985, p. 244. 
portas através das quais, em fins do século XVIII, o café teria adentrado os limites da capitania ${ }^{17}$. De fato, a localidade em tela, com pouco menos de 103 mil arrobas em 1836, era então a principal produtora de café da província ${ }^{18}$. No Almanak da Província de São Paulo para 1873 faz-se constar que "a principal cultura de seu Município é a do café". Eram 36 os fazendeiros listados no mencionado Almanak, cinco dos quais igualmente compondo o conjunto formado por meia dúzia de capitalistas. Naquele ano de 1873, havia 12 negociantes de fazendas, armarinho, ferragens e molhados, e outros 16 armazéns de molhados e gêneros do país ${ }^{19}$.

$\mathrm{O}$ vínculo da cidade com a cafeicultura foi indicado, com ênfase ainda maior, nos Apontamentos de Manuel Eufrásio de Azevedo Marques, publicados originalmente em 1879, nos quais lemos, no verbete dedicado a Areias: "a lavoura quase exclusiva é a do café" ${ }^{20}$. O comportamento da lavoura cafeeira ao longo do século XIX em Areias ajustou-se de maneira exemplar à seguinte caracterização, feita por Sergio Milliet, e afeta à zona por ele denominada Norte (Vale do Paraíba e litoral norte paulistas) como um todo:

Nesta zona exclusivamente de progresso cafeeiro, que nenhuma cultura nova veio salvar, cujas comunicações com os grandes centros são difíceis, melhor ressaltam as relações entre a economia e a demografia. Estamos em cheio na zona morta, que o café desbravou, povoou, enriqueceu e abandonou antes que criasse raízes o progresso ${ }^{21}$.

Guaratinguetá, comparada a Areias, era mais próxima da capital da província paulista (as distâncias eram, respectivamente, de 36 e 48,5

17 A outra dessas portas sugeridas é Jundiaí, onde o sargento-mor Raymundo Alves dos Santos Prado Leme teria iniciado a plantação de café com sementes recebidas de presente do governador Melo Castro e Mendonça, em 1797 (cf. TAUNAY, Affonso de E. História do café no Brasil. Rio de Janeiro: Departamento Nacional do Café, 15 v., 1939, v. 2, p. 331-332).

18 Cf. MÜLLER, Daniel P. Ensaio d'um quadro estatístico da província de São Paulo: ordenado pelas leis municipais de 11 de abril de 1836 e 10 de março de 1837. 3. ed. fac-similada. São Paulo: Governo do Estado, 1978, p. 124.

19 Cf. LUNÉ; FONSECA, op. cit., p. 244 e 246-249.

20 MARQUES, Manuel Eufrásio de Azevedo. Apontamentos históricos, geográficos, biográficos, estatísticos e noticiosos da Província de São Paulo, seguidos da cronologia dos acontecimentos mais notáveis desde a fundação da Capitania de São Vicente até o ano de 1876. São Paulo: Comissão do IV Centenário da Cidade de São Paulo, 2 v., 1953, v. 1, p. 91.

21 MILLIET, Sergio. Roteiro do café e outros ensaios: contribuição para o estudo de história econômica e social do Brasil. São Paulo: s.ed., 1939, p. 40, grifo nosso. 
léguas). Também localizado no Vale do Paraíba, o povoado de Santo Antônio de Guaratinguetá foi fundado em 1646, integrando um dos ramos do movimento de expansão do povoamento paulista, para leste da Vila de São Paulo de Piratininga ${ }^{22}$. A elevação do núcleo guaratinguetano à categoria de vila ocorreu em 1656, e à de cidade em 1844. Na segunda metade do Oitocentos, caminhou vigorosamente para o auge de sua produção cafeeira, a qual, “(...) em 1836, de 22.442 arrobas, eleva-se em 1854 a 100.885 e em 1886, seu período áureo, a 350.000 arrobas, decaindo sensivelmente depois"23. Em verdade, esta última cifra, fornecida por Lucila Herrmann, parece deveras modesta quando defrontada com o relato de Augusto Emílio Zaluar, que principiou uma viagem pela província paulista nos meses derradeiros do ano de 1859:

A cultura principal deste município consiste no café, que anualmente exporta entre quinhentas e seiscentas mil arrobas. Cultiva-se também a cana, de que se faz a rapadura bastante para o consumo local; fabrica-se algum açúcar, e faz-se em grande escala a cultura de gêneros alimentícios ${ }^{24}$.

No que respeita ao conjunto das atividades agrárias de Guaratinguetá, é uma vez mais oportuna a transcrição das observações de Azevedo Marques, atinentes a meados dos anos de 1870:

O principal ramo de lavoura deste município é o café, que produz abundantemente, e de que exporta 300.000 arrobas, termo médio, anualmente, por Parati e Ubatuba para o mercado do Rio de Janeiro. Também exporta algum algodão, posto que em pequena quantidade. Cultiva-se ali a cana-de-açúcar, o fumo e cereais para consumo. Uma parte da população dedica-se também à pesca no rio Paraíba, que em certas épocas do ano fornece abundante peixe ${ }^{25}$.

22 Cf. MÜLLER, Nice Lecoq. O fato urbano na Bacia do Rio Paraíba, Estado de São Paulo. Rio de Janeiro: Fundação IBGE, 1969, p. 14-19.

23 HERRMANN, Lucila. Evolução da estrutura social de Guaratinguetá num periodo de trezentos anos. Ed. fac-similada. São Paulo: IPE/USP, 1986, p. 115.

24 ZALUAR, Augusto Emílio. Peregrinação pela província de São Paulo (1860-1861). Belo Horizonte: Itatiaia. São Paulo: EDUSP, 1975, p. 80.

25 MARQUES, op. cit., v. 1, p. 307. 
Portanto, Guaratinguetá, vis-à-vis Areias, era uma povoação mais antiga, de fato uma das mais antigas da província. Todavia, situada, expressemo-nos assim, "mais a oeste", foi mais tardiamente alcançada pelo café. Por conta dessas características, distinguia-se de Areias, no período por nós analisado, pelo maior volume de sua produção cafeeira, bem como pela maior multiplicidade verificada em termos das atividades ligadas ao comércio. Assim, no Almanak de 1873 foram listados, além de 129 fazendeiros e 2 capitalistas, 30 lojas de fazendas, 55 armazéns de secos e molhados, um armarinho, uma loja de calçados, uma loja de arreios, selas etc. e 12 negociantes de tropa solta ${ }^{26}$.

Em região distinta do Vale do Paraíba, radicada no que poderíamos denominar "Oeste Velho" da província paulista, em 1769 foi criada a Freguesia de Santo Antonio de Piracicaba, elevada à "categoria de Vila em 1822, sendo substituído o seu primitivo nome pelo de Constituição, e foi elevada a cidade em 1856 "27. Apenas na segunda metade do decênio de 1870 o nome do município foi alterado para Piracicaba. Maria Thereza Petrone, em seu estudo sobre a lavoura canavieira paulista, referindo-se especificamente a Piracicaba, escreveu:

Em 1854 existiam 51 fazendas de cana com uma produção de 131.000 arrobas. (...) A obsessão do café não atingiu a região, pelo menos até essa data. O cultivo da cana em Piracicaba, como em Itu, continuou progredindo, não sendo afetado pela penetração do café, como aconteceu em Campinas. Itu e Piracicaba, os vales do Tietê e do Piracicaba, portanto, eram, em meados do século passado [XIX-JFM], os redutos da cana-de-açúcar ${ }^{28}$.

Daí as características da lavoura cafeeira, na abertura da década de 1860 , na localidade de Constituição, conforme explicitadas uma vez mais por Zaluar, características estas que diferenciam essa cidade dos dois municípios vale-paraibanos:

26 Cf. LUNÉ; FONSECA, op. cit., p. 205-211.

27 Cf. LUNÉ; FONSECA, op. cit., p. 462.

28 PETRONE, Maria Thereza Schorer. A lavoura canavieira em São Paulo. Expansão e declínio (1765-1851). São Paulo: Difusão Europeia do Livro, 1968, p. 49. 
A sua produção de café e açúcar regula, termo médio, em cento e cinquenta mil arrobas. É preciso notar que a cultura do café é aqui de data muito recente, pois ainda há muito pouco tempo os Piracicabanos se entregavam exclusivamente ao cultivo da cana, que com esta inovação tem consideravelmente diminuído ${ }^{29}$.

Na década de 1870, tanto no Almanak de 1873, como nos Apontamentos de Azevedo Marques, ainda que sejam mencionados o café e o açúcar como principais produções de Piracicaba, é já aquele, e não este, o que vem em primeiro lugar. E, em 1886, Sergio Milliet referiu uma produção cafeeira de 300.000 arrobas em Piracicaba ${ }^{30}$.

Por fim, o quarto município que selecionamos para análise foi Casa Branca. Conforme registrado no Almanak de 1873, esta localidade, "sendo Freguesia pertencente ao Município de Mogi-Mirim, foi elevada à categoria de Vila em 1841, com a denominação de Nossa Senhora das Dores de Casa Branca, e à de cidade a 27 de Março de 1872" "31. Na direção "Oeste", trilhada pela marcha do café, Casa Branca situa-se a cerca de dois terços do caminho entre a capital da província e Ribeirão Preto, esta última, na primeira metade da década de 1870 , "nova e ainda pouco importante povoação" ${ }^{32}$, mas que viria a ser o centro do assim chamado "Oeste Novo" paulista. Em meados daquele mesmo decênio, no verbete dedicado a Casa Branca, Azevedo Marques observava que "a lavoura do município é o açúcar, cereais e algum café; também há fazendas de criação de gado"33.

Não obstante, no mencionado Almanak de 1873, o arrolamento dos cultivos trazia, antes dos demais, o café: “(...) cultiva-se café, cana-de-açúcar, fumo, algodão e gêneros alimentícios" ${ }^{\prime 3}$. De acordo com as tabulações efetuadas por Sergio Milliet, a produção de café do município igualou-se a 1.750 arrobas em 1854, atingindo a marca de 300 mil arrobas em 1886. Nesse último ano, na zona definida por Milliet como da Mogiana, a produção cafeeira de Casa Branca superou a de todas as demais locali-

29 ZALUAR, op. cit., p. 151, grifo nosso.

30 Cf. MARQUES, op. cit., v. 1, p. 197-199, LUNÉ; FONSECA, op. cit., p. 462 e MILLIET, op. cit., p. 43.

31 Cf. LUNÉ; FONSECA, op. cit., p. 491.

32 MARQUES, op. cit., v. 2, p. 209.

33 MARQUES, op. cit., v. 1, p. 173, grifo nosso.

34 LUNÉ; FONSECA, op. cit., p. 494. 
dades, com a única exceção de Amparo, que àquele ano produziu mais de 900 mil arrobas da rubiácea ${ }^{35}$.

Em suma, no decurso dos decênios de 1860, 1870 e 1880, a economia dos quatro municípios em foco, com maior ou menor intensidade, foi marcada pela lavoura cafeeira. O avanço no tempo da "onda verde" levaria a opulência às áreas da vanguarda da expansão cafeeira, ao passo que deixaria um cenário de decadência nas áreas pioneiras da cafeicultura paulista. Na feliz comparação de Monteiro Lobato, o café avançou "como um Átila"36. Evidentemente, as vicissitudes dessa expansão foram condicionantes de peso do tráfico interno de escravos registrado naqueles municípios. $\mathrm{E}$, em meio àquele tráfico, tais vicissitudes afetaram também o comércio de cativos idosos.

\section{A comercialização de escravos velhos}

Aos 5 de dezembro de 1885, Gabriel Antonio Ferreira vendeu, por dois contos e duzentos mil réis, três escravos para Vicente Osias de Sillas. O comprador residia na cidade de Casa Branca e o vendedor no termo de São João da Boa Vista, ambas localidades paulistas. Os cativos transacionados eram João, de 35 anos, e o casal David e Maria, ele africano e ela crioula, respectivamente com 62 e 27 anos de idade. Na escritura o Tabelião informava: "Acompanha a escrava Maria seus filhos ingênuos de nomes Joaquim, Vicência, Elias, Delfina, Maria e Domingas, todos averbados na Coletoria desta cidade". Ao término do documento, ao que parece, deu-se conta do "inconveniente" representado pela idade do africano! Procedeu-se ao acréscimo, pois, de um "Em tempo: o escravo David é apenas vendido os seus serviços e não a sua pessoa, visto ser maior de sessenta anos como consta da matrícula acima transcrita". Embora haja sempre a possibilidade de avançarmos uma interpretação equivocada, é difícil não inferir um efeito meramente "semântico" da Lei dos Sexagenários, datada de menos de dois 
meses antes do registro descrito, sobre a venda daquele cativo avançado em anos.

Nossas fontes documentais são registros como esse, de transações envolvendo escravos, efetuados em Areias, Guaratinguetá, Constituição (Piracicaba) e Casa Branca nas décadas derradeiras do período escravista brasileiro. Como ilustrado na seção precedente deste artigo, o movimento da "onda verde" cafeeira, proveniente do Vale do Paraíba e demandante do Oeste histórico da Província de São Paulo, conformou o pano de fundo do tráfico humano aqui analisado. A venda mencionada no parágrafo anterior, objeto de escritura lançada em Casa Branca, parece-nos muito oportuna para abrir a análise acerca da comercialização de escravos velhos. Uma vez que ainda não atingira os 65 anos em dezembro de 1885, David, apesar de "liberto" pela Lei n. ${ }^{\circ} 3.270$, não se livrou da obrigação dos três anos de serviços "a título de indenização pela sua alforria", conforme disposto no $\S 10$ do Artigo $3 .^{\circ}$ da lei, anteriormente transcrito.

Na Tabela 1, indicamos os totais de escravos e o contingente de cativos idosos objeto das transações registradas no conjunto das localidades selecionadas ${ }^{37}$. Os 27 anos em tela foram segmentados em quatro intervalos menores, para o que adotamos, em linhas gerais, a caracterização realizada por Gorender do comércio interno de escravos pós-extinção do tráfico transatlântico ${ }^{38}$. A essa caracterização acrescentamos a divisão dos anos de

37 Apenas para o caso de Constituição (Piracicaba) encontramos escrituras datadas em todos os anos do intervalo temporal considerado. As lacunas, a nosso ver, decorreram muito mais da não preservação de alguns dos livros notariais ou do mero insucesso em localizá-los até o momento, do que da eventual inexistência de transações envolvendo escravos.

38 "Os anos cinquenta foram marcados pela grande prosperidade europeia, que suscitou extraordinária demanda dos produtos de exportação dos países escravistas sobreviventes (Brasil, Cuba e Estados Unidos). [...] É de supor que a força maior de atração das regiões cafeeiras encontrou resistência por parte dos plantadores de cana-de-açúcar, algodão e tabaco do Nordeste. A intensa transferência de escravos nordestinos para o Sudeste cafeeiro deve ter ocorrido [...] às custas dos setores onde o escravo era menos rentável do que nas plantagens exportadoras ou mais fácil de ser dispensado: escravos domésticos, artesãos e outros escravos urbanos, escravos empregados na pecuária.

$[\ldots]$

"Os anos sessenta foram marcados pela confluência de dois movimentos inversos. A Guerra de Secessão nos Estados Unidos (1861-1865) abriu o mercado inglês ao algodão brasileiro, o que beneficiou os plantadores nordestinos. [...] Enquanto isso, a produção cafeeira do Sudeste diminuiu o ritmo de crescimento, afetada pela crise bancária de 1864 e por alguns anos de cotações baixas. [...] Os plantadores nordestinos se encontraram, então, em melhores condições para disputar a mão de obra escrava de suas regiões e o tráfico em direção ao Sudeste sofreu decréscimo de intensidade.

"Nos anos setenta, o boom algodoeiro se desvaneceu e a produção cafeeira retomou vigoroso impulso ascensional. A Lei do Ventre Livre de setembro de 1871 arrefeceu o movimento abolicionista e 
1870 em duas partes (1870-1873 e 1874-1880), procurando melhor captar o impacto, decerto destacado naqueles princípios da década, das discussões prévias e da vigência inicial da Lei do Ventre Livre sobre aquele comércio.

TABELA 1 - ESCRAVOS IDOSOS E TOTAL DE CATIVOS TRANSACIONADOS SEGUNDO SEXO EANO DO REGISTRO (LOCALIDADES SELECIONADAS, 1861-1887)

\begin{tabular}{c|c|c|r|r|r}
\hline \multirow{2}{*}{ Períodos } & \multicolumn{3}{|c|}{ Escravos Idosos } & \multirow{2}{*}{$\begin{array}{c}\text { Total de } \\
\text { Cativos }\end{array}$} & $\begin{array}{c}\text { Porcentual } \\
\text { de Idosos }\end{array}$ \\
\cline { 2 - 5 } & Homens & Mulheres & Total & & \\
\hline $1861-1869$ & 22 & 15 & 37 & 783 & 4,7 \\
$1870-1873$ & 32 & 13 & 45 & 615 & 7,3 \\
$1874-1880$ & 40 & 13 & 53 & 1.578 & 3,4 \\
$1881-1887$ & 44 & 14 & 58 & 701 & 8,3 \\
$\mathbf{1 8 6 1 - 1 8 8 7}$ & $\mathbf{1 3 8}$ & $\mathbf{5 5}$ & $\mathbf{1 9 3}$ & $\mathbf{3 . 6 7 7}$ & $\mathbf{5 , 2}$ \\
\hline
\end{tabular}

FONTE: Escrituras de transações envolvendo escravos.

De início, considerado todo o período 1861-1887, percebemos que os idosos perfizeram pouco mais de um vigésimo (5,2\%) do total das pessoas comercializadas ${ }^{39}$. Notamos, ademais, que a maior participação dos idosos (8,3\%) ocorreu no período 1881-1887, quando a imposição de elevados tributos à entrada de escravos na província limitou sobremaneira o comércio interprovincial; quando se alargava, pela própria passagem do tempo, o efeito da libertação dos nascituros em 1871, reduzindo a quantidade de crianças cativas e aumentando o contingente dos ingênuos; e também quando, afinal, evidenciou-se o caráter moribundo da instituição escravista ${ }^{40}$.

deu ao regime escravocrata renovada estabilidade política. Tais fatores conduziriam o preço do escravo ao ponto mais alto do século XIX, no Sudeste cafeeiro, alcançando o escravo masculino na força da idade, entre 20 e 25 anos, mais de 2:000\$000 no final da década dos setenta" (GORENDER, op. cit., p. 326-328). O período contemplado pelas escrituras por nós compulsadas condicionaram o não tratamento da primeira das fases mencionadas por Gorender. E, como não nos limitamos às transações interprovinciais, nossa periodização avança também no decênio de 1880 .

39 Não obtivemos o informe da idade de 69 cativos. Se os excluíssemos, o total reduzir-se-ia para 3.608 e a participação dos idosos alçar-se-ia a 5,4\%.

40 "The Rio Bill levied a registration tax of 1:500\$ on slaves brought from other provinces, and was passed in mid-December, 1880. The Minas bill created a tax of 2:000\$, and was passed in late December, 1880. The São Paulo bill also created a tax of two contos, and became law on January 15, 1881." 
A segunda mais alta participação dos idosos (7,3\%) foi atingida nos anos próximos à promulgação da Lei do Ventre Livre (1870-1873), nos quais o tráfico de cativos ressentiu-se das incertezas então presentes em termos do destino das mercadorias humanas; dependendo da localidade considerada, o arrefecimento havido naquele comércio foi sentido, sobretudo, nas transações interprovinciais. No caso de Piracicaba, por exemplo, verificamos que, "naqueles anos fundamentais para o evolver da legislação abolicionista, os negócios com escravos em Constituição estiveram em especial concentrados nos limites da própria localidade" $"$.

Em contrapartida, a menor participação dos idosos foi observada no período 1874-1880 (tão somente 3,4\%), quando o tráfico interno sem dúvida vivenciou seus melhores dias. $\mathrm{E}$ foi apenas um pouco mais elevada nos anos de 1860 (4,7\%), nos quais o comércio de cativos apresentou, para usarmos a expressão de Gorender, intensidade moderada, embora tenha sido também expressivo. Adicionalmente, salientemos, no intervalo 18741880 foi alcançada, para aquele comércio, a maior contribuição dada pelos negócios entre distintas províncias do Império.

Ao considerarmos a informação sobre o sexo das pessoas transacionadas, notamos que a razão de sexo (número de homens para cada grupo de 100 mulheres) igualou-se a 164 para o conjunto dos escravos e elevou-se a 251 se computados apenas os velhos. A disparidade desses indicadores foi crescente nos quatro intervalos temporais considerados. Nos anos de 1860, as ditas razões de sexo foram relativamente próximas (147 para os idosos e 139 para o total). Em torno da libertação dos nascituros (1870-1873), o predomínio de homens entre os velhos (246) foi já significativamente maior

[SLENES, Robert Wayne. The demography and economics of brazilian slavery: 1850-1888. Tese (Doutorado em História) - Stanford University. Stanford, 1976, p. 124-125]. O mencionado "caráter moribundo" da escravidão é ilustrado pela queda dos preços dos cativos, em especial a partir de 1883. Ver, por exemplo: sobre o crash do tráfico interno de escravos no Brasil, SLENES, Robert Wayne. The Brazilian Internal Slave Trade, 1850-1888: Regional Economies, Slave Experience, and the Politics of a Peculiar Market. In: JOHNSON, Walter (Ed.). The Chattel Principle: Internal Slave Trades in the Americas. New Haven \& London: Yale University Press, 2004, p. 325-370. E, sobre o comportamento dos preços de cativos em algumas localidades paulistas em fins do período escravista, ver MOTTA, José Flávio. Derradeiras transações: o comércio de escravos nos anos de 1880 (Areias, Piracicaba e Casa Branca, província de São Paulo). Almanack Braziliense, revista eletrônica, São Paulo, IEB/USP, n. 10, novembro de 2009. Disponível em: $<$ http://www.almanack.usp.br/>.

41 MOTTA, José Flávio. Escravos daqui, dali e de mais além: o tráfico interno de cativos em Constituição (Piracicaba), 1861-1880. Revista Brasileira de História, São Paulo, ANPUH, v. 26, p. 15-47, jul./dez. 2006, p. 31. 
do que o verificado no total das transações (172). A diferença alargou-se no período 1874-1880 (308 para os idosos e 177 para o total), e mais ainda nos sete anos derradeiros que compõem nossa análise (respectivamente, $314 \mathrm{e}$ 159). Vale dizer, se os homens foram sempre mercadoria mais frequentemente negociada do que as mulheres, essa disparidade entre os sexos foi maior quando o objeto do comércio era avançado em anos, e isto ocorreu de modo crescente ao longo do tempo.

Sobrepõem-se, pois, duas ordens de considerações. Nas transações registradas antes de 1874, o mercado para homens velhos expandiu-se nos anos em que o ritmo do tráfico perdeu alento. Isto igualmente ocorreu nos negócios registrados após 1873; todavia, no contexto da vigência da Lei do Ventre Livre, a crescente escassez de cativos jovens tornava necessariamente os mais velhos um bem não facilmente prescindível. O peso relativo das transações com idosos, aliado à distribuição dessas pessoas segundo o sexo, revelou ainda um elemento constante por todas as quase três décadas examinadas: a pequena atratividade possuída pela mercadoria representada pelas escravas velhas.

No cômputo das escrituras compulsadas, valemo-nos do informe sobre o local de moradia dos contratantes para segmentarmos as transações em três tipos: "locais" (residência na própria localidade onde se fez o registro ou em seu termo); "intraprovinciais" (envolvendo contratantes moradores em outras localidades paulistas); e "interprovinciais" (envolvendo contratantes residentes nas demais províncias do Império $)^{42}$. Nos Gráficos 1 e 2 , respectivamente para o total de cativos negociados e para o contingente formado pelos idosos, apresentamos as participações relativas desses três tipos de comércio, calculadas para cada um dos quatro intervalos temporais considerados.

Não consideramos, para a construção do Gráfico 2, 10 pessoas $(5,2 \%)$ do total de 193 idosos, cinco delas transacionadas nos anos de 1860 , duas no período 1874-1880 e outras três nos anos de 1880. No Gráfico 1 não foram computadas 129 pessoas negociadas no intervalo 1861-69, 28 em 1870-1873, 82 em 1874-1880 e 46 no período 1881-1887; vale dizer,

42 Não podemos descartar a possibilidade de que o critério utilizado, em alguns casos, tenha implicado aventarmos movimentações de cativos diferentes das que efetivamente ocorreram. Todavia, tais casos decerto abrangeram tão somente uma minoria das pessoas negociadas, razão pela qual não cremos que comprometam os resultados de nossa análise. 
285 escravos $(7,7 \%)$ do contingente de 3.677 cativos registrados na documentação analisada. Esse procedimento, na maior parte dos casos, deveu-se à inexistência da informação acerca do local de moradia dos contratantes nas respectivas escrituras.

GRÁFICO 1 - ESCRAVOS NEGOCIADOS SEGUNDO TIPO DO TRÁFICO (LOCALIDADES SELECIONADAS, 1861-1887)

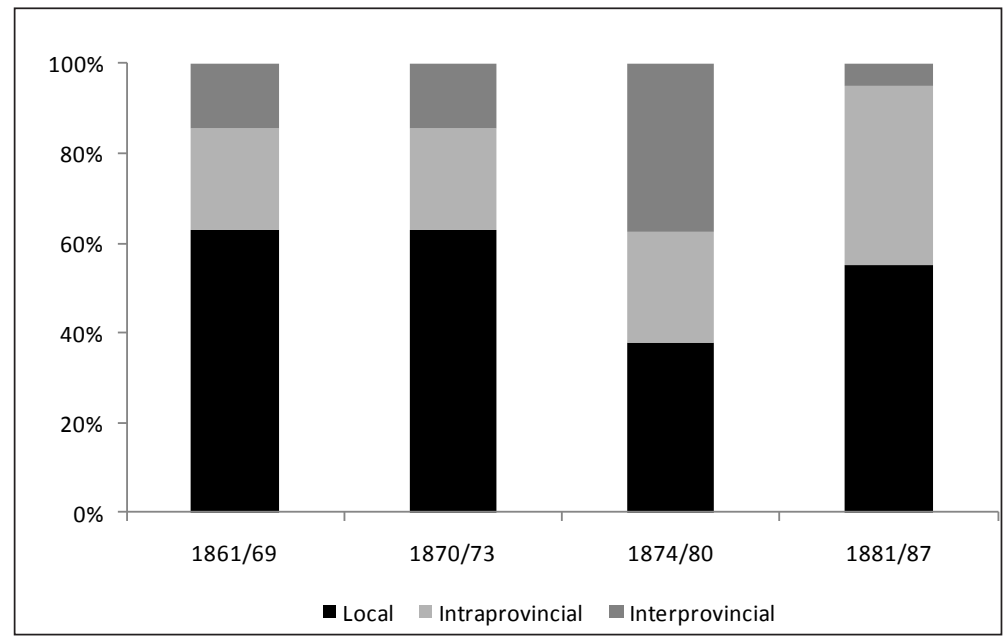

FONTE: Escrituras de transações envolvendo escravos.

Comparando os dois gráficos percebemos, com clareza, que o comércio de velhos não era um ramo relevante do tráfico entre províncias. É certo que, mesmo para o conjunto das pessoas negociadas, o comércio interprovincial nunca compreendeu a maioria absoluta dos escravos; atingiu, no máximo, em 1874-1880, uma proporção próxima de dois quintos deles (37,5\%). Mas essa proporção máxima, no caso dos idosos, alcançada no mesmo intervalo temporal, foi muito menor (15,7\%). Assim, durante os 27 anos considerados, apenas uma dúzia de cativos velhos foram adquiridos de, ou enviados para, outras unidades do Império. Esse o caso, por exemplo, de Luis, de 50 anos, natural de Santa Catarina e matriculado naquela província, em São Sebastião de Tijucas, vendido por João Francisco Furtado, também residente naquela localidade. Manoel Ferraz de Arruda Campos, morador 

(LOCALIDADES SELECIONADAS, 1861-1887)

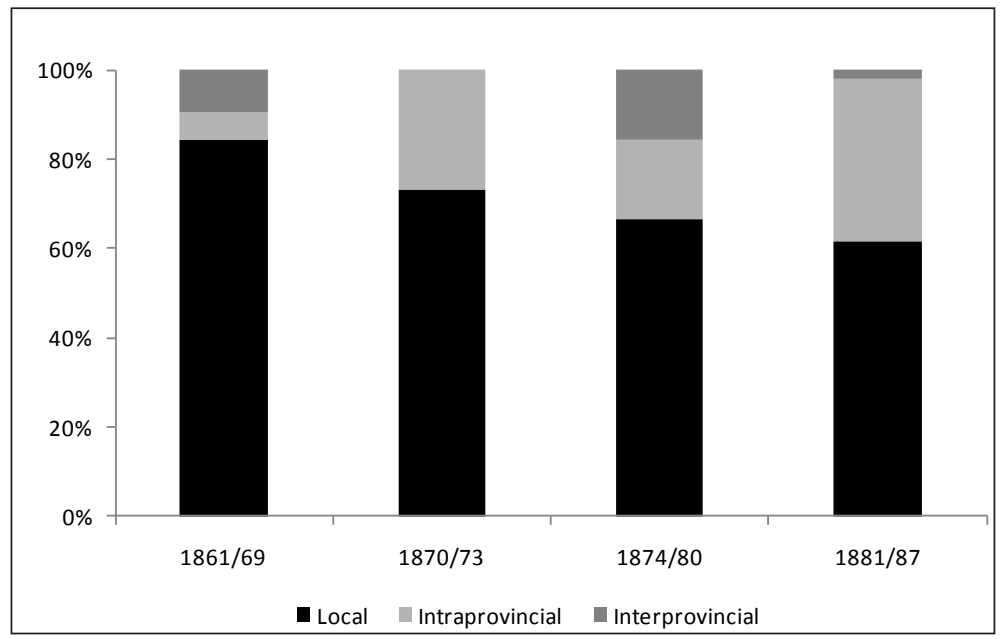

FONTE: Escrituras de transações envolvendo escravos.

em Piracicaba, atuou como procurador de Furtado nessa venda registrada em julho de 1874. O negócio envolveu cinco escravos além de Luis, cujos proprietários, todos representados por Manoel, residiam em Lajes e São José, duas outras localidades de Santa Catarina ${ }^{43}$. O comprador, Pedro Ferraz de Arruda Campos, de Piracicaba, era decerto parente do procurador dos vendedores.

Outro caso dessa dúzia de cativos idosos negociada no tráfico interprovincial deve ser descrito com maior detalhe. Isto por conta de a escritura ser datada no último dos períodos que consideramos, mais precisamente aos 16 de julho de 1885. Naquele dia, em Areias, um conjunto de 16 escravos foi vendido pelo Capitão Joaquim Simões da Cunha para o Tenente-Coronel José Fernandes Nunes, por Rs. 16:800\$000. Entre as pessoas vendidas estava Justino, viúvo de 54 anos de idade, de cor preta, do serviço da lavoura. Natural de Pouso Alegre, Justino havia sido matriculado 
naquela localidade de Minas Gerais e posteriormente averbado em Areias. $\mathrm{O}$ vendedor residia nesse município paulista e tanto ele como o comprador estavam presentes no ato e assinaram a escritura. Mas o Tenente-Coronel José Nunes era morador de Resende, no Rio de Janeiro. Na província fluminense, tal como na paulista e na mineira, desde o início da década vigia um imposto elevado incidente sobre o comércio de escravos vindos de outras províncias ${ }^{44}$. Talvez o destino desses 16 cativos não fosse, ao fim e ao cabo, o Rio de Janeiro; ou talvez seu comprador conhecesse meios de fugir ao pagamento do tributo devido ao entrar com sua aquisição naquela província vizinha.

O maior dinamismo do tráfico interno de escravos no período 18741880 não só torna relativamente menos relevante o fluxo de idosos (como vimos com base na Tabela 1), mas igualmente amplia as disparidades entre os negócios em geral e as transações de velhos no tocante à distribuição por tipo de tráfico. O contrário observa-se nos anos de 1880, quando não apenas a participação relativa dos idosos atinge seu máximo (cf. Tabela 1), como também se apresentam muito similares as distribuições por tipo de tráfico do conjunto das transações e daquelas envolvendo cativos de idade mais avançada. Já os dois primeiros períodos são aqueles nos quais foi maior o predomínio dos negócios de âmbito local, predomínio este mais intenso no caso dos velhos (84,4\% em 1861-1869 e 73,3\% em 1870-1873), mas também expressivo nos negócios em geral (em torno de $63 \%$ nos dois intervalos em tela).

Na Tabela 2 fornecemos alguns dados adicionais sobre as idades dos escravos transacionados. Obtivemos esse informe para 3.608 pessoas, isto é, $98,1 \%$ do total. Tomado o período como um todo, a idade média desses mais de três milhares e meio de cativos igualou-se a 24,46 anos; o mesmo indicador, calculado para os 193 velhos, alçou-se a 55,59 anos. É possível percebermos com nitidez o envelhecimento das pessoas transacionadas. No conjunto dos idosos, a sempre crescente idade média aumentou quase dois

44 Ver notas 40 e 42 acima. Do total de 701 escravos transacionados no período 1881-1887, apenas cerca de um vigésimo (5,3\%) foram-no via tráfico interprovincial. Foram 34 pessoas, a grande maioria (28) vendida para compradores residentes em outras províncias; maioria ainda mais expressiva dessas pessoas (30) foi negociada em Areias. Nessa localidade vale-paraibana, o Tenente-Coronel José Nunes, além da escritura registrada em julho de 1885, efetuou duas outras compras, aos 26 e 27 de fevereiro daquele mesmo ano, respectivamente, de cinco e três escravos. Assim, esse único comprador foi responsável por 70,6\% dos cativos transacionados entre províncias por nós computados no intervalo 1881-1887. 
anos e meio entre 1870-1873 e 1874-1880, e novamente mais de dois anos entre 1874-1880 e 1881-1887. Os acréscimos da idade mediana ratificam esse processo de envelhecimento. Parece evidenciar-se, aí, o impacto na escravaria da Lei do Ventre Livre. A inexistência de novas gerações de trabalhadores compulsórios acarretaria o prolongamento do uso do estoque pré-existente de trabalhadores compulsórios e, por conta disso, elevaria a média etária dos velhos integrantes do fluxo do comércio interno de cativos.

E é igualmente significativo notarmos como, para o conjunto dos escravos negociados, a elevação mais substancial da idade média só ocorreu nos anos de 1880. Em verdade, a idade média de 23,39 anos em 1874-1880, menor até do que a calculada para o período 1870-1873, também refletiu a vigência da libertação dos nascituros. Em trabalho anterior, concernente às localidades paulistas de Guaratinguetá e Silveiras no decurso da década de 1870, o acompanhamento dos preços dos escravos de acordo com distintas faixas etárias auxilia-nos agora a esclarecer um pouco melhor esse efeito:

[...] a elevação de preços havida no caso dos cativos com idades de 10 a 14 anos (84,3\% para os homens e $41,2 \%$ para as mulheres) supera as calculadas entre os escravos de 15 a 24 anos $(25,2 \%$ para ambos os sexos) e de 25 a 34 anos $(31,0 \%$ para homens e $25,8 \%$ para mulheres). É possível que, sob o efeito da Lei do Ventre Livre, de 1871, tenham-se valorizado de maneira mais que proporcional exatamente aqueles cativos,

TABELA 2 - IDADES MÉDIAS DOS ESCRAVOS EM GERAL E DOS CATIVOS IDOSOS, POR PERÍODOS (MÉDIA, MEDIANA E DESVIO-PADRÃO; LOCALIDADES SELECIONADAS, 1861-1887)

\begin{tabular}{c|c|c|c|c}
\hline \multirow{2}{*}{ Períodos } & Idades Médias dos & \multicolumn{3}{|c}{ Idades dos Cativos Idosos } \\
\cline { 3 - 5 } & Escravos em Geral & Média & Mediana & Desvio-Padrão \\
\hline $1861-1869$ & 22,08 & 53,06 & 50,00 & 4,934 \\
$1870-1873$ & 23,91 & 53,87 & 50,00 & 6,010 \\
$1874-1880$ & 23,39 & 56,19 & 55,00 & 5,132 \\
$1881-1887$ & 30,15 & 58,28 & 58,00 & 5,699 \\
$\mathbf{1 8 6 1 - 1 8 8 7}$ & $\mathbf{2 4 , 4 6}$ & $\mathbf{5 5 , 5 9}$ & $\mathbf{5 5 , 0 0}$ & $\mathbf{5 , 8 5 9}$ \\
\hline
\end{tabular}

FONTE: Escrituras de transações envolvendo escravos. 
em especial os do sexo masculino, cuja expectativa de vida em cativeiro fosse mais longa. Afinal, ainda que a eficácia dessa lei para a efetiva libertação dos nascituros seja discutível, e a utilização dos "serviços" dos ingênuos uma prerrogativa dos seus "proprietários" (de fato, proprietários de suas mães), é evidente que a reposição da mão de obra escrava não se daria mais nos mesmos moldes que antes ${ }^{45}$.

A elevação das idades média e mediana dos cativos velhos vincula-se, outrossim, ao comportamento observado da razão de sexo. Como apontamos anteriormente, a dita razão superou a cifra de 300 entre os idosos nos períodos de 1874-1880 e 1881-1887. E, enquanto os 138 homens velhos negociados tinham idade média igual a 56,42 anos, as 55 mulheres eram relativamente mais jovens: idade média de 53,49 anos. As idades medianas de idosos e idosas foram, respectivamente, de 55,00 e 52,00 anos; as idades deles variaram do mínimo estabelecido por nosso critério, de 50 anos, ao máximo de 80 , enquanto as delas atingiram no máximo 65 anos. Se nos lembrarmos das estimativas de longevidade dos escravos calculadas por Pedro Carvalho de Mello, e das quais nos servimos na primeira seção deste artigo, verificamos que as expectativas de vida foram sempre superiores para as mulheres. Não obstante, as idades médias dos cativos idosos negociados pareceriam contraditar as estimativas de Mello. Aparência, a nosso ver, enganosa; o que se evidencia, de fato, é a já citada pouca atratividade representada pela mercadoria "mulher idosa" 46 .

Em suma, esse fluxo de pessoas com 50 ou mais anos de idade respondia em parte, decerto, a uma demanda por mão de obra que se via crescentemente moldada por uma oferta que se ressentia das características assumidas pelo evolver da questão servil, reduzindo cada vez mais a

45 MOTTA, José Flávio; MARCONDES, Renato Leite. O comércio de escravos no Vale do Paraíba paulista: Guaratinguetá e Silveiras na década de 1870. Estudos Econômicos, São Paulo, IPE/USP, v. 30, n. 2, p. 267-299, abr./jun. 2000, p. 280.

46 Essa aparente contradição entre maiores expectativas de vida das mulheres e menores idades médias das cativas velhas transacionadas poderia, é claro, ser também em parte explicada por um acesso diferenciado das idosas à alforria. Em outras palavras, as idosas mais idosas não apareceriam entre as pessoas velhas negociadas pelo fato de terem sido libertadas, o que ocorreria com menor frequência no caso dos homens idosos. Alternativamente, poder-se-ia aventar que as velhinhas fossem particularmente valorizadas por seus proprietários, que delas não se desfaziam; esta última possibilidade, porém, não parece encontrar amparo, ao menos no comportamento dos preços praticados nas transações envolvendo aquelas pessoas. 
disponibilidade de braços cativos, num movimento que teria seu corolário na abolição da escravatura, em 1888. Em outras palavras, para vários dos compradores dessas pessoas, um escravo de 50 ou mais anos poderia não ser o ideal, porém sempre seria melhor do que escravo nenhum. Talvez esse tenha sido o raciocínio feito por Moyses Pereira de Arruda. Morador em Piracicaba, ele aparece uma única vez negociando nos anos de 1880. Aos 11 de abril de 1885, Moyses adquiriu de Joaquim Antonio Barbosa, também morador naquela localidade, o escravo Januário, de cor preta, solteiro e com 58 anos de idade. A transação de compra e venda limitava-se a esse único cativo, pelo qual o comprador pagou seiscentos mil-réis.

Não obstante a possibilidade acima descrita houve também casos, na verdade a grande maioria deles, nos quais a negociação não se limitou aos escravos mais velhos. De fato, amiúde tem-se mesmo a impressão de que eles nem eram o objeto principal da transação. Exemplo bem ilustrativo é dado pela venda de David, descrito no início desta seção e escolhido para compor a epígrafe deste artigo. Esse africano, com 62 anos, foi comprado por um morador de Casa Branca em dezembro de 1885, juntamente com sua esposa, Maria (27 anos), acompanhada por seis filhos ingênuos, além de João (35 anos), este último sem nenhum laço de parentesco com os demais, ao menos que tenha sido indicado na escritura que sacramentou o negócio. Ora, é difícil imaginarmos que o foco do interesse dos contratantes fosse David, ainda mais em data na qual já vigia a Lei dos Sexagenários. Afinal, a legislação em vigor proibia a separação entre Maria e seus filhos ingênuos, e também vetava a separação entre Maria e David ${ }^{47}$. Vale dizer, se o interesse do comprador estivesse muito mais focado na expectativa dos vários anos de serviços a serem cumpridos pelas crianças "libertas" pela Lei do Ventre

47 Naqueles últimos lustros de vigência da escravidão no Brasil, como se sabe, produziu-se uma legislação com vistas a coibir a separação entre cônjuges e entre pais e filhos cativos. Foi o caso do Decreto n. ${ }^{\circ} 1.695$, de 15 de setembro de 1869 , que em seu artigo $2 .^{\circ}$ dispunha: "em todas as vendas de escravos, ou sejam particulares ou judiciais, é proibido, sob pena de nulidade, separar o marido da mulher, o filho do pai ou mãe, salvo sendo os filhos maiores de 15 anos". (Coleção de Leis do Império do Brasil, 1808-1889. Atos do Poder Legislativo de 1869. Disponível em: <http://www2.camara.gov.br/legislacao/ publicacoes/doimperio>. Acesso em: 19 de maio de 2008). Em 1871, na Lei Rio Branco (n. 2.040, de 28 de setembro), o artigo $4 .^{\circ}, \S 7 .^{\circ}$, estabelecia um novo limite de idade para as separações das crianças: "Em qualquer caso de alienação ou transmissão de escravos é proibido, sob pena de nulidade, separar os cônjuges, e os filhos menores de 12 anos, do pai ou mãe." (Coleção de Leis do Império do Brasil, 1808-1889. Atos do Poder Legislativo de 1871. Disponível em: < http://www2.camara.gov.br/legislacao/publicacoes/ doimperio>. Acesso em: 19 de maio de 2008). 
Livre, na verdade a pessoa de David, e não os seus serviços, é que seria o elemento mais relevante a explicar sua inclusão no lote comercializado.

Enquanto 1.139 (31,0\%) dos 3.677 indivíduos por nós analisados foram o único objeto negociado pelos contratantes descritos nas respectivas escrituras, o porcentual correlato, no caso dos cativos velhos, caiu aproximadamente pela metade (16,1\%). Apenas 31 dos 193 idosos não integravam transações nas quais outros escravos estavam envolvidos. E, mesmo nesses 31 casos, havia quatro viúvos, dois de cada sexo, e cinco pessoas casadas, três homens e duas mulheres, sendo que para um deles, João Banqueiro, de 60 anos, constava a informação de ser casado com cônjuge liberta. A venda de indivíduos casados, sozinhos, fossem eles velhos ou não, poderia ser uma maneira de obter algum acesso à mão de obra dos cônjuges. Nos casos da existência de esposas libertas, a propriedade do marido, idoso ou não, igualmente poderia permitir algum acesso à mão de obra da eventual prole existente, quiçá livre ${ }^{48}$. Esta última possibilidade, é conveniente mencionarmos, talvez não fosse o fator mais importante na venda de João Banqueiro, ao que parece um trabalhador com alguma especialização na produção do açúcar que, apesar de sexagenário, poderia compensar os Rs. $450 \$ 000$ que custou ao seu comprador, Doutor Felipe Xavier da Rocha, residente em Piracicaba, em junho de $1882^{49}$.

A grande maioria dos escravos velhos (162 dos 193), portanto, foi negociada juntamente com outros cativos. Nessas transações envolvendo duas ou mais pessoas, foi expressiva a presença de relações familiares: mais de três quintos $(61,7 \%)$ daqueles 162 idosos possuíam vínculos de família que pudemos identificar com os indivíduos com eles negociados. Foram, por exemplo, 60 os idosos (39 homens e 21 mulheres) que compunham casais sem filhos presentes. E outros 33 velhos (29 homens e 4 mulheres)

48 Também os viúvos poderiam, eventualmente, ser um instrumento facilitador do acesso à mão de obra de uma possível prole livre ou liberta.

49 A escritura de compra e venda de João não explicita essa especialização na descrição do escravo; contudo, a dita especialização pode ser inferida do nome a ele atribuído. Alice Canabrava, nos "Vocábulos e expressões usados em Cultura e opulência" que elaborou para uma das edições da obra de Antonil, escreveu: "Soto-mestre ou banqueiro - Substituto do mestre [de açúcar-JFM] no período noturno. Seu ajudante é o soto-banqueiro, em geral um mulato ou crioulo escravo da casa" [ANDREONI, João António (André João Antonil). Cultura e opulência do Brasil (Texto da edição de 1711). Introdução e Vocabulário por A. P. Canabrava. 2. ed. São Paulo: Companhia Editora Nacional, 1966, p. 119] Além de assumir à noite as funções do mestre do açúcar, escreveu Antonil, "tem mais, por obrigação, o banqueiro, repartir de noite o açúcar pelas formas, assentá-las no tendal e consertá-las com cipó” (ANDREONI, op. cit., p. 200). 
foram transacionados junto com seus cônjuges e filhos, fossem estes últimos também escravos ou ingênuos, havendo casos em que parte da prole era cativa e parte liberta pela lei de setembro de 1871 . Houve também viúvos e viúvas acompanhados de filhos (escravos e/ou ingênuos), bem como uma velha solteira com sua prole.

Aos 12 de julho de 1879 foi registrada, em Piracicaba, a escritura de venda de uma dúzia de escravos, bem como a transferência dos direitos sobre os serviços de seis ingênuos, que ilustra bem a presença expressiva de relações familiares nas transações que analisamos e que envolveu também um africano idoso, Primo, de 54 anos. O negócio, de âmbito local, foi acertado entre Antonio Bento de Camargo e Inocêncio de Paula Eduardo. Inocêncio pagou catorze contos e novecentos mil-réis pelos seguintes cativos: Primo, sua esposa Ignez (41 anos) e os cinco filhos do casal (Benedita, 19; Albina, 14; Maria, 12; Francisco, 10 e Carlos, 8); o casal Bento e Francisca, respectivamente de 32 e 27 anos de idade; e os irmãos (ao menos por parte de mãe) Amador (20), Marcolino (19) e Sebastião (15). Das seis crianças ingênuas cujos serviços eram mencionados no documento, duas eram filhas de Ignez, uma era filha de Benedita, portanto neta de Ignez, e três eram filhas de Francisca ${ }^{50}$.

Verificamos, no conjunto de documentos por nós trabalhado, que Primo e Ignez, já casados, haviam sido adquiridos com duas de suas filhas, Benedita e Albina, então com, respectivamente, seis e um anos de idade, em 2 de novembro de 1865. Essa primeira transação também ocorrera localmente, envolvendo dois contratantes moradores em Constituição. A

50 Ainda que as transações com a mercadoria humana fossem sempre ocasiões difíceis para a manutenção das famílias escravas, em muitos casos, ao menos em parte, as relações familiares foram preservadas pelo tráfico interno. De fato, quanto a esta questão, por exemplo, com base em dados de oito das maiores fazendas de Paraíba do Sul, na província do Rio de Janeiro, e mediante a utilização de inventários post-mortem como fontes documentais, Fragoso e Florentino observaram que "dos 1.171 escravos comprados até 1872 , nada menos que $33,6 \%$ estavam unidos por laços de parentesco de primeiro grau (casais com filhos e mães solteiras e seus rebentos), dado que aponta na direção da existência de um mercado de famílias na região" (FRAGOSO, João Luis Ribeiro; FLORENTINO, Manolo Garcia. Marcelino, filho de Inocência Crioula, neto de Joana Cabinda: um estudo sobre famílias escravas em Paraíba do Sul, 18351872. Estudos econômicos. Demografia da escravidão. São Paulo: IPE/USP, v. 17, n. 2, p. 151-173, maio/ ago. 1987, p. 164, negritos no original). Para uma crítica dessa sugestão aventada por Fragoso e Florentino ver, por exemplo, ANDRADE, Rômulo. Havia um mercado de famílias escravas? (A propósito de uma hipótese recente na historiografia da escravidão). LOCUS: Revista de História, Juiz de Fora: UFJF, v. 4, n. 1, p. 93-104, 1998; esse autor, que estuda dois municípios cafeeiros da Zona da Mata de Minas Gerais (Juiz de Fora e Muriaé), baseou-se, tal como nós, em escrituras de compra e venda de cativos. De todo modo, a manutenção parcial das famílias nas vendas foi decerto estimulada pela legislação referida na nota 47. 
família fora comprada de Joaquim Fernandes de Sampaio, por quatro contos de réis, pelo Reverendo Vigário Joaquim Cypriano de Camargo. É bastante plausível sugerir que Antonio Bento de Camargo tenha em algum momento herdado o plantel de escravos do Reverendo, ou parte dele. O certo é que no intervalo de cerca de catorze anos entre as duas negociações, aquela família escrava cresceu bastante e passou, pelo menos relativamente, "incólume" por alguns momentos críticos (as duas vendas e, provavelmente, também uma partilha).

Para algo como metade dos escravos idosos (95 indivíduos, 49,2\%), obtivemos a informação acerca da atividade produtiva para a qual tais pessoas eram consideradas aptas. Computamos esse informe quando explicitado na descrição do escravo feita na escritura, razão pela qual, por exemplo, João Banqueiro não aparece na distribuição apresentada na Tabela 3. Não apenas é elevado o número de velhos de aptidão não sabida, como também é muito grande o predomínio de roceiros e roceiras entre aqueles com aptidão descrita: 84 em 95, ou seja, quase nove décimos (88,4\%), mesmo sem somar aos 84 os 3 escravos que, além da roça, estavam aptos para uma segunda atividade (casa, cozinha e pedreiro). Foram, portanto, pouquíssimos os idosos detentores de um saber ocupacional mais especializado, que poderia atuar como um diferencial a atrair a demanda sobre eles ${ }^{51}$.

Por fim, um comentário concernente aos preços dos idosos. Quando as transações envolviam mais de um cativo, era comum que o valor da escritura fosse referente ao conjunto negociado. Além disso, após a libertação dos nascituros, a menção aos ingênuos, cujos serviços eram transferidos como direito do vendedor ao comprador da mãe escrava, que eles, ingênuos, por determinação legal, deveriam acompanhar, torna difícil nesses casos determinar se aquelas crianças não teriam alguma influência no valor do negócio ${ }^{52}$. Uma vez que muitos dos velhos foram transacionados "em família", às vezes com ingênuos presentes (a exemplo do africano David), e outros ainda (a exemplo do catarinense Luis) junto com escravos que não eram seus familiares, a quantidade de preços "aproveitáveis" foi muito reduzida.

$51 \mathrm{O}$ serviço da roça também era a ocupação mais frequente dos escravos em geral, todavia com um predomínio menos intenso do que o verificado para os de 50 ou mais anos de idade. A proporção de roceiros e roceiras entre os cativos negociados para os quais se descrevia alguma aptidão não atingiu os três quartos $(70,7 \%)$.

52 No caso dos sexagenários, vale observação similar, uma vez que também ocorria a transferência dos serviços dos idosos libertos pela Lei de 1885, como vimos no exemplo de David. 
TABELA 3 - DISTRIBUIÇÃO DOS ESCRAVOS IDOSOS SEGUNDO SEXO E APTIDÃO DECLARADA NA ESCRITURA (LOCALIDADES SELECIONADAS, 1861-1887

\begin{tabular}{c|c|c}
\hline Aptidão & Homens & Mulheres \\
\hline Serviço da roça/da lavoura & 62 & 22 \\
Serviço doméstico & - & 3 \\
Serviço de roça e cozinha & - & 1 \\
Serviço de casa e roça & - & 1 \\
Serviço de roça e pedreiro & 1 & - \\
Carapina & 1 & - \\
Ferreiro & 1 & - \\
Pedreiro & 1 & - \\
Lavadeira & - & 1 \\
Apto para todo o trabalho & 1 & - \\
Sem informação & 71 & 27 \\
Total & $\mathbf{1 3 8}$ & $\mathbf{5 5}$ \\
\hline
\end{tabular}

FONTE: Escrituras de transações envolvendo escravos.

Assim sendo, apenas para formarmos alguma ideia acerca dos preços relativos, tomamos os escravos com 50 ou mais anos para todo o intervalo 1861-1887. Conseguimos 33 informes de preços dessas pessoas de maior idade, 22 de homens e 11 de mulheres. As médias, em termos nominais, igualaram-se, respectivamente, a Rs. $851 \$ 818$ e Rs. $552 \$ 818$. Apresentamos na Tabela 4, como referencial para comparação, os preços médios nominais de escravos adultos jovens, isto é, com idades de 15 a 29 anos, preços esses computados segundo o sexo e de acordo com três períodos. É digno de nota o alargamento havido, no período 1870-1880, no diferencial entre os preços de homens e mulheres, evidência palpável da desvalorização sofrida pelas mulheres após a libertação do ventre da escrava. Percebemos então que a média calculada para as idosas, algo inferior a seiscentos mil-réis, atingiu no máximo pouco mais de dois terços $(68,6 \%)$ dos preços médios das adultas jovens nos anos derradeiros do período escravista, proporção que se reduziu para pouco mais de dois quintos $(41,5 \%)$ quando são computados os preços das adultas jovens nos anos de 1860.

As mesmas comparações produzem resultados um pouco mais favoráveis no que respeita aos valores atribuídos aos escravos homens 
com 50 ou mais anos de idade. Seu preço médio correspondeu a quase oito décimos $(78,9 \%)$ dos preços médios dos homens adultos jovens no intervalo 1881-1887. Tomado o período 1861-1869, esse porcentual reduz-se para $51,2 \%$, também quase dez pontos porcentuais superior ao calculado para as idosas. Apenas quando consideramos o intervalo com os mais elevados preços médios dos adultos jovens do sexo masculino (1870-1880), a média dos preços dos homens velhos atinge uma proporção (41,9\%) que é ligeiramente inferior à proporção correlata calculada para o caso das mulheres $(42,2 \%)$. Ainda que o pequeno número de preços válidos para os escravos velhos, fossem homens ou mulheres, demande cautela na interpretação, parece-nos ratificar-se aqui, novamente, a pequena atratividade da mercadoria representada pelas escravas velhas.

TABELA 4 - PREÇOS MÉDIOS NOMINAIS DOS ESCRAVOS ADULTOS JOVENS SEGUNDO SEXO E PERÍODO DE REGISTRO DA ESCRITURA(CATIVOS DE 15 A 29 ANOS DE IDADE; LOCALIDADES SELECIONADAS, 1861-1887)

\begin{tabular}{c|c|c}
\hline Sexo / Períodos & Número de Escravos & Preços médios (em réis) \\
\hline Homens & 90 & $1: 662 \$ 322$ \\
$1861-1869$ & 326 & $2: 031 \$ 349$ \\
$1870-1880$ & 77 & $1: 079 \$ 870$ \\
$1881-1887$ & 67 & \\
\hline Mulheres & 147 & $1: 332 \$ 074$ \\
$1861-1869$ & 55 & $806 \$ 182$ \\
$1870-1880$ & & \\
$1881-1887$ &
\end{tabular}

FONTE: Escrituras de transações envolvendo escravos.

O maior preço pago por um idoso referiu-se a um negócio realizado em Guaratinguetá. De maneira nada surpreendente, tratou-se da venda de um escravo homem, no limite inferior da faixa etária por nós considerada; ademais, a transação ocorreu quando os preços dos cativos atingiram seus maiores níveis, em fins da década de 1870. Assim, em 12 de dezembro de 1878, Dona Francisca Rosalina dos Santos Reis, através de seu procurador, Francisco da Costa Reis, vendeu para Antonio Miranda de Carvalho, todos residentes em Guaratinguetá, o escravo preto de nome Bento, de nação, solteiro, com 50 anos de idade, apto para todo o trabalho e que já havia sido 
matriculado no mesmo município, anos atrás. O preço pelo qual Bento foi vendido superou os dois contos de réis (Rs. 2:100\$000).

No extremo oposto, o menor preço igualou-se a cem mil-réis. Foram dois casos. O primeiro, em Guaratinguetá. Numa transação de âmbito local, em 27 de maio de 1874, Feliciana Maria de Jesus vendeu para Alexandre da Silva Vilella o velho Pedro, africano de 60 anos de idade, cujo estado conjugal não foi informado. Alguns meses depois, em $1 .^{\circ}$ de dezembro daquele mesmo ano, em Piracicaba, em outro negócio local, Antonio Mendes de Almeida vendeu sua cativa Francisca para Antonio José de Oliveira Bastos. Francisca tinha 52 anos, era preta, solteira e crioula, natural da província de São Paulo, tendo sido matriculada no início da década lá mesmo em Piracicaba. Em nenhuma dessas duas escrituras há qualquer informe adicional, por exemplo, a descrição de algum "defeito", que pudesse justificar os baixos preços obtidos com as vendas de Pedro e Francisca.

\section{Considerações finais}

Com base, em especial, nas escrituras de transações envolvendo escravos, registradas nos municípios de Areias, Guaratinguetá, Constituição (Piracicaba) e Casa Branca no período 1861-1887, voltamos nossa atenção neste artigo para o comércio de cativos velhos, assim entendidas as pessoas com 50 ou mais anos de idade. No intervalo temporal contemplado, as localidades selecionadas tiveram seu desenvolvimento em boa medida condicionado pela expansão cafeeira no território da província de São Paulo, expansão esta que, decerto, foi fator importante a conformar a intensidade e demais características do comércio interno de escravos e, nele, do tráfico de cativos idosos. Para a definição da faixa etária das pessoas objeto de nosso estudo, valemo-nos de estimativas da longevidade de escravos no Brasil na segunda metade do século XIX, bem como de indicações reveladoras dos interesses dos escravistas.

Os idosos perfizeram cerca de um vigésimo $(5,2 \%)$ do total das pessoas transacionadas no conjunto dos 27 anos cobertos pelos documentos compulsados. Mas essa participação foi maior $(8,3 \%)$ no período 1881 1887 e menor em 1874-1880 (3,4\%). Adicionalmente, cresceu ao longo do 
tempo o predomínio de homens entre os velhos negociados e este predomínio foi sempre maior do que o verificado para o conjunto dos escravos traficados. Como regra geral, percebemos que a importância do fluxo de idosos mostrou-se inversamente proporcional à intensidade do comércio da mercadoria humana. E foi também de fundamental relevância a vigência da Lei do Ventre Livre, quando a crescente escassez de cativos jovens implicou necessariamente a impossibilidade de aquele comércio prescindir das pessoas de mais idade.

Verificamos uma destacada supremacia, no tráfico de velhos, das transações realizadas no universo local. E a distribuição dos negócios pelos diferentes tipos de tráfico (local, intraprovincial e interprovincial), no caso dos idosos, mostrou-se mais distinta da observada para o conjunto dos escravos exatamente quando o comércio de cativos vivenciava seu maior dinamismo, no período 1874-1880. Ao contrário, nos derradeiros anos do tráfico, entre 1881 e 1887, aquela distribuição, no caso dos idosos, foi muito próxima da calculada para o total das pessoas transacionadas.

Houve nitidamente, no decurso do período analisado, um envelhecimento das pessoas transacionadas. Para o fluxo do comércio como um todo, esse envelhecimento foi substancial nos anos de 1880, uma vez que o mercado, na etapa anterior, de maior dinamismo (1874-1880), procurou lidar com o impacto da libertação dos nascituros pela preferência, evidenciada no comportamento dos preços, dada às aquisições, pelos municípios cafeeiros, de escravos bastante jovens, uma vez que com eles poder-se-ia estender ao máximo o usufruto da escravidão. Entre os velhos, os maiores acréscimos nas idades médias e medianas acompanharam a elevação da razão de sexo, refletindo mais uma vez o impacto da Lei do Ventre Livre, que tornou as idosas a mercadoria menos interessante do tráfico interno de escravos.

Embora algumas dezenas de velhos tenham sido objeto de negócios nos quais uma única pessoa era traficada, a grande maioria deles integrou transações compostas por grupos de cativos. Foi também expressiva a presença de relações familiares identificadas entre os idosos e muitas das pessoas com eles negociadas. De fato, ainda que não se possa descartar in limine a importância da mão de obra desses velhos para os proprietários de escravos que os demandavam, em muitos casos a presença dos idosos pareceu-nos representar a parte menos importante da negociação efetuada. Sua venda, amiúde, era em certa medida forçada pela existência de legislação 
impeditiva da separação entre cônjuges e entre pais e filhos. Vale dizer, é plausível sugerirmos que muitos compravam escravos velhos "a reboque" da aquisição de outros cativos, familiares desses idosos, ou mesmo como mecanismo de acesso à mão de obra de pessoas livres ou libertas, também detentoras de relações familiares com os escravos de mais idade.

Por fim, quase nove décimos dos velhos para os quais era descrita na escritura a atividade/ocupação para a qual estavam aptos eram roceiros. Nada indica que o peso da idade significasse haver alguma diminuição no processo de exploração inerente ao instituto da escravidão. Não obstante, a capacidade necessariamente mais reduzida para o trabalho aparecia refletida nos preços em média mais baixos praticados nos negócios envolvendo essas pessoas. Estivessem ou não alquebrados pelos muitos anos de trabalho forçado, os escravos idosos continuaram sendo transacionados até data relativamente próxima da abolição. Enquanto a última das escrituras cujas informações coletamos referia-se à venda de meia dúzia de cativos e havia sido registrada em Casa Branca aos 12 de outubro de 1887, a última venda de um velho por nós computada ocorreu em Areias, quase exatamente um ano antes.

Em 11 de outubro de 1886, Galdino, de 50 anos, solteiro, foi vendido juntamente com Salvador (48) e Alexandrina (37), todos negros e do serviço da lavoura. No documento lemos que Salvador era casado com cônjuge liberta e que Alexandrina, solteira, era acompanhada por dois filhos ingênuos. Pelos três escravos, o major Laurindo José de Carvalho Penna pagou Rs. 1:300\$000 para Antonio Corrêa Pacheco, ambos moradores naquele município do Vale do Paraíba, recebendo o major o direito ao usufruto dos serviços dos dois ingênuos, na conformidade da lei. $\mathrm{O}$ trio vendido era natural também de Areias e lá os três haviam sido matriculados na primeira metade da década de 1870. Só podemos especular até que ponto Pacheco e o major Laurindo, de um lado, e Alexandrina, Salvador e o velho Galdino, de outro, imaginavam, naquele outubro de 1886, um futuro assemelhado com aquilo que a realidade lhes revelaria em maio de 1888 .

Recebido em 07/10/2009.

Aprovado em 14/12/2009. 